\title{
Penggunaan Google Classroom dan Zoom Meeting dalam Menunjang Pelaksanaan Pembelajaran PPKn Selama Masa Pandemi Covid-19 pada Kelas Xii APHP 1 SMKN Wongsorejo
}

\author{
Yanti Devi Wijaya \\ SMK Negeri Wongsorejo, Banyuwangi, Jawa Timur \\ yantideviwijaya1@gmail.com
}

\begin{abstract}
Abstrak
Selama masa pandemi covid-19 pelaksanaan pembelajaran di sekolah harus dilaksanakan secara online atau dalam jaringan (daring), hal ini untuk mencegah penyebaran virus covid-19 demi kesehatan dan keselamatan warga sekolah, guru, peserta didik, keluarganya, dan juga masyarakat. Untuk itu membutuhkan strategi dan penyesuaian yang harus dilakukan oleh guru dan peserta didik. Tidak sedikit kendala dalam pelaksanaan pembelajaran PPKn selama masa pandemi covid-19 yang dialami dalam pembelajaran daring, apalagi pada masyarakat Wongsorejo, yang terletak di ujung Utara Kabupaten Banyuwangi, yang merupakan ujung Timur Pulau Jawa, dimana para peserta didik sebagian besar dari keluarga menengah ke bawah. Penelitian aplikatif yang penulis lakukan ini terkait dengan penggunaan google classroom dan zoom meeting dalam pembelajaran PPKn pada kelas XII APHP (Agribisnis Pengolahan Hasil Pertanian) 1 yang merupakan salah satu strategi yang penulis terapkan dalam pembelajaran selama masa pandemi covid-19. Dalam praktiknya, kedua aplikasi tersebut dapat menunjang pelaksanaan pembelajaran dengan tergambar dari hasil pembelajaran, meski menunjukan hasil dengan grafik yang naik dan turun, yang perlu untuk dilakukan evaluasi guna penelitian untuk solusi lebih lanjut guna keberhasilan pembelajaran.
\end{abstract}

Kata kunci: pandemi covid-19, google classroom, zoom meeting, pembelajaran PPKn

\begin{abstract}
During the COVID-19 pandemic, the implementation of learning in schools must be carried out online or online, this is to prevent the spread of the Covid-19 virus for the health and safety of school residents, teachers, students, their families, and also the community. This requires strategies and adjustments that must be made by teachers and students. Not a few obstacles in implementing Civics learning during the COVID-19 pandemic experienced in online learning, especially in the Wongsorejo community, which is located at the northern tip of Banyuwangi Regency, which is the eastern tip of Java Island, where most of the students come from lower-middle families. . This applicative research that the author is doing is related to the use of google classroom and zoom meetings in Civics learning in class XII APHP (Agribusiness Processing Agricultural Products) 1 which is one of the strategies that the author applies in learning during the covid-19 pandemic. In practice, these two applications can support the implementation of learning by depicting the learning outcomes, even though they show results with graphs that go up and down, which need to be evaluated for research for further solutions for successful learning.
\end{abstract}

Keywords: covid-19 pandemic, google classroom, zoom meeting, Civics learning

\section{PENDAHULUAN}

Wabah coronavirus disease (Covid19) sudah menyerang lebih dari 185 negara dan wilayah di seluruh dunia (Santika, 2020b). Coronavirus adalah salah satu patogen utama yang menargetkan terutama sistem pernafasan manusia. Wabah coronavirus termasuk Middle East Respiratory Syndrome (MERS)-CoV dan Severe acute Respiratory Syndrome (SARS)
(Hamid, Mir, \& Rohela, dalam Yo Ceng Giap, 2020). Coronavirus berbentuk bulat dengan diameter sekitar $125 \mathrm{~nm}$ dapat dilihat menggunakan cryo-electron tomografi dan mikroskopi cryo-elektron (Venkat Kumar, Jeyanthi, \& Ramakrishnan, dalam Yo Ceng Giap, 2020).

Dikutip dari Hamid, et al., 2020, Yo Ceng Giap menyatakan, bahwa Coronavirus 
pertama kali ditemukan pada bulan Desember 2019 di Wuhan, Provindi Hubei Cina. Sejumlah pasien dirawat di rumah sakit karena gangguan pernafasan, pasien-pasien ini diketahui telah mengkonsumsi makanan laut. Coronavirus ditularkan pertama kali melalui hewan seperti hewan basah atau makanan laut. Gejala infeksi Covid-19 mulai muncul setelah suatu masa inkubasi 5-6 hari. Periode waktu antara timbulnya gejala Covid-19 ke kematian berkisar antara 6-41 hari dengan median 14 hari. Jangka waktu ini tergantung pada sistem kekebalan dan usia pasien (Swarniti, 2020).

Pada tanggal 7 Januari 2020, Badan Kesehatan Dunia (WHO) memberikan nama virus tersebut 2019 novel coronavirus (2019nCov) dan pada tanggal 11 Maret 2020 menyatakan Covid-19 sebagai pandemi untuk seluruh negara di dunia (Naserghandi, Allameh, \& Saffarpour, dalam Yo Ceng Giap, 2020). WHO merekomendasikan salah satu cara memutus penyebaran Covid-19 adalah dengan menerapkan pembatasan perjalanan, karantina, pembatasan jam malam, pengendalian bahaya di tempat kerja, dan penutupan fasilitas umum (Santika et al., 2021).

Pada tanggal 2 Maret 2020, Presiden Joko Widodo mengumumkan kasus pertama Covid-19 di Indonesia. Kasus pertama di Indonesia ini menimpa dua orang warga Depok, Jawa Barat. Salah satu korban covid-19 tersebut diketahui telah berkumpul bersama rekanrekannya dan salah satu dari rekan tersebut merupakan warga negara Jepang yang terkena wabah Covid-19. Setelah beberapa hari diketaui korban mengalami gejala sakit dan sang ibu membantu mengurusi korban yang sebagai anak kandungnya. Sang ibu pun akhirnya tertular Covid-19 dari anaknya (Ihsanuddin dalam Yo Ceng Giap, 2020)

Kasus penyebaran Covid-19 di Indonesia terus meningkat. Berdasarkan data Kementerian Kesehatan Republik Indonesia melalui laman http://covid19.go.id/ hingga tanggal 10 Mei 2020 tercatat sebanyak 13.645 kasus terkonfirmasi, 10.079 dalam perawatan, 2.607 sembuh, dan 959 meninggal dunia (Yo Ceng Giap, 2020).

Pandemi Covid-19 ini juga berdampak pada dunia pendidikan. Pada tanggal 17 Maret 2020, pemerintah melalui Kementerian Pendidikan dan Kebudayaan mengeluarkan Surat Edaran Nomor 36963/MPK.A/HK/2020 tentang Pembelajaran secara daring dan bekerja dari rumah dalam rangka pencegahan penyebaran oronavirus disease (Covid-19), yang merupakan salah satu upaya pemerintah untuk memutus mata rantai dan mencegah penyebaran coronavirus disease (Covid-19).

Berdasarkan Surat Edaran dari Kementerian Pendidikan dan Kebudayaan tersebut, beserta Surat Edaran Gubernur Jawa Timur Nomor 420/1780/101.1/2020 tertanggal 15 Maret 2020 perihal Peningkatan Kewaspadaan terhadap Coronavirus Disease (Covid-19) di Jawa Timur, dan berkaitan pula dengan Surat Kepala Cabang Dinas Pendidikan Wilayah Kabupaten Banyuwangi Nomor 421/0501/101.6.7/2020 tertanggal 16 Maret 2020 perihal Pelaksanaan Kegiatan di Sekolah Berbasis Ponpes dan Asrama serta Prakerin dalam Kewaspadaan terhadap Penyebaran Virus Corona, maka kepala SMKN Wongsorejo mengeluarkan pemberitahuan kepada semua 
warga sekolah, peserta didik, dan orang tua/wali peserta didik sebagai tindak lanjut dalam rangka pencegahan penyebaran virus corona dengan isi sebagai berikut:

1. Siswa Kelas $X$ belajar di rumah mulai tanggal 16-19 Maret 2020;

2. Siswa Kelas XI yang melaksanakan Praktik Kerja Lapangan (PKL) dilakukan penarikan lebih awal dari tempat PKL bagi siswa yang sudah melaksanakan PKL 6 (enam) bulan sampai akhir bulan Maret 2020, dan menarik sementara dari tempat PKL bagi siswa yang baru melakukan PKL pada bulan Maret 2020 sampai waktu penyerahan kembali setelah tanggal 29 Maret 2020;

3. Pelaksanaan kegiatan ekstrakurikuler atau kegiatan siswa lainnya di luar kegiatan belajar mengajar terhitung tanggal 16-29 Maret 2020 diliburkan;

4. Siswa Kelas XII melaksanakan UNBK tanggal 16-19 Maret 2020, selanjutnya belajar di rumah sampai 29 Maret 2020;

5. Semua mempersiapkan diri untuk mengikuti kegiatan pembelajaran secara daring (online). Guru menyiapkan materi dan metode pembelajaran online;

6. Harap Wali Kelas aktif berkomunikasi dengan orang tua/wali siswa;

7. Menghimbau kepada orang tua/wali siswa untuk mengawasi dan menjaga putra/putrinya tetap di rumah, selalu menjaga kebersihan, mengurangi kegiatan di luar rumah, dan yang beresiko, serta jika terdapat gejala-gejala sakit segera memeriksakan diri ke dokter, Puskesmas, atau fasilitas kesehatan lainnya. Mohon Bapak/Ibu/ Orang
tua/Wali siswa aktif berkomunikasi dengan sekolah melalui Wali Kelas.

Dari berbagai hal yang sudah terurai di atas, maka peneliti sebagai tenaga pendidik pada SMK Negeri Wongsorejo harus melakukan transformasi metode pengajaran dari yang semula secara konvensional dengan tatap muka secara langsung dengan peserta didik di kelas, wajib melaksanakan pembelajaran secara online, e-learning yang pasti harus mampu dengan mengintegrasikan teknologi informasi dan komunikasi dalam pelaksanaannya. Inilah yang membuat peneliti mencoba menggunakan google classroom dan zoom meeting guna menunjang pelaksanaan pembelajaran PPKn pada kelas XII APHP 1 SMKN Wongsorejo.

Dari latar belakang yang sudah terurai di atas, peneliti merumuskan masalah "apakah dengan menggunakan google classroom dan zoom meeting dapat menunjang pelaksanaan pembelajaran PPKn pada Kelas XII APHP 1 di SMKN Wongsorejo selama masa pandemi covid-19?"

Penelitian ini difokuskan pada penggunaan google classroom dan zoom meeting pada pelaksanaan pembelajaran PPKn pada peserta didik di Kelas XII APHP 1 SMKN Wongsorejo pada Semester Gasal Tahun Pelajaran 2020/2021.

Penelitian ini bertujuan agar dapat menunjang kelancaran pelaksanaan pembelajaran, dan mengembangkan kemampuan guru dan peserta didik dalam pelaksanaan pembelajaran dengan mengintegrasikan teknologi informasi dan komunikasi dalam pelaksanaan pembelajaran, sehingga diharapkan akan dapat menunjang 
pelaksanaan pembalajaran online selama masa pandemi covid-19, khususnya di Kelas XII APHP 1 SMKN Wongsorejo Semester Gasal Tahun Pelajaran 2020/2021.

Dengan penelitian ini diharapkan akan bermanfaat menambah pengetahuan dan pengalaman guru sebagai peneliti dan peserta didik dalam penerapan pembelajaran dengan mengintegrasikan teknologi informasi dan komunikasi dalam pelaksanaan pembelajaran secara online di masa pandemi covid-19, serta untuk mengetahui apa kendala-kendala yang dihadapi dalam penerapan pembelajaran dengan menggunakan google classroom dan zoom meeting pada pembelajaran PPKn pada kelas XII APHP 1 di SMKN Wongsorejo selama masa pandemi covid-19, untuk dapat menjadi bahan evaluasi lebih lanjut.

\section{METODE}

Dalam penelitian ini penulis mengambil sampel penerapan pembelajaran pada peserta didik kelas XII APHP 1 SMKN Wongsorejopada pembelajran PPKn di Tahun pelajaran 2020/2021.

Pertama penulis telah merencanakan dengan menyiapkan Rencana Pelaksanaan Pembelajaran secara online atau daring setelah menganalisa Kompetensi Dasar yang akan diajarkan sesuai dengan kebijakan kurikulum darurat yang diterapkan di sekolah. Kemudian membuat panduan penggunaan google classroom dalam pembelajaran dari menggali berbagai sumber literasi, dan menerapkan pembelajaran, yang dilanjutkan dengan observasi pelaksanaan pembelajaran dan hasil pembelajaran, serta melakukan refleksi dari hasil observasi.

Kerangka Metode Penelitian

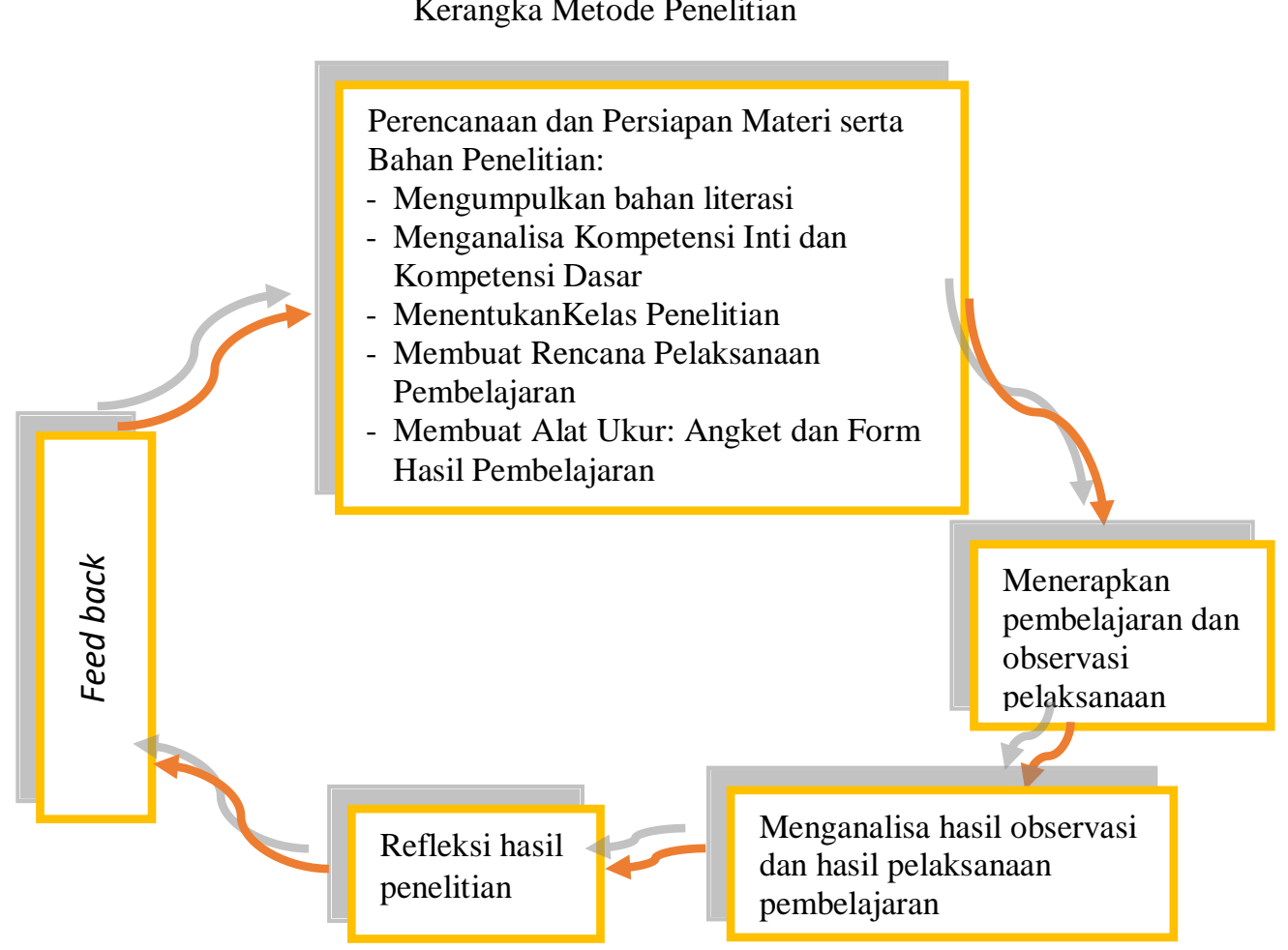




\section{HASIL DAN PEMBAHASAN}

Kelas XII APHP 1 adalah salah satu rombongan belajar yang ada pada SMK Negeri Wongsorejo. APHP adalah salah satu kompetensi keahlian yang ada pada SMKN Wongsorejo, yaitu kompetensi keahlian Agribisnis Pengolahan Hasil Pertanian, yang mana kompetensi keahlian ini mempelajari tentang berbagai macam ilmu pengetahuan tentang bagaimana menangani dan mengolah bahan-bahan hasil pertanian, seperti Penanganan Bahan Hasil Pertanian, Pengolahan Bahan Hasil Pertanian, Pengendalian Mutu Hasil Pertanian, Produksi Pengolahan Hasil Nabati, Produksi Pengolahan Hasil Hewani, Produksi Pengolahan Komoditas Perkebuan dan Herbal, Keamanan Pangan, Penyimpanan, dan Penggudangan, serta Produk Kreatif dan Kewirausahaan.

Sucahyono MJ. (2016) menuliskan bahwa Pendidikan Pancasila dan Kewarganegaraan merupakan mata pelajaran dengan visi utama sebagai pendidikan demokrasi yang bersifat multidimensional. Ia merupakan pendidikan nilai demokrasi, pendidikan moral, pendidikan sosial, dan masalah pendidikan politik. Namun yang paling menonjol adalah sebagai pendidikan nilai dan pendidikan moral (Santika, 2021b). Oleh karena itu secara singkat Pendidikan Pancasila dan Kewarganegaraan dinilai sebagai mata pelajaran yang mengusung misi pendidikan nilai dan moral (Santika, 2020a). Berdasarkan uraian di atas tampak bahwa pada hakikatnya terjadinya perubahan nama mata pelajaran
Pendidikan Kewarganegaraan menjadi Pendidikan Pancasila dan Kewarganegaraan dimaksudkan untuk mengokohkan jati diri pelajaran tersebut sebagai pendidikan nilai dan moral yang bertumpu pada empat pilar kebangsaan: Pancasila, UUD 1945, Bhinneka Tunggal Ika, dan Negara Kesatuan Republik Indonesia (Santika, 2021c). Panduan ini disusun untuk memberikan petunjuk teknis bagi para guru agar dapat menyelenggarakan pembelajaran dan penilaian Pendidikan Pancasila dan Kewarganegaraan di sekolah sesuai dengan jati dirinya yang baru tersebut (Santika et al., 2018).

$$
\text { Sucahyono MJ. (2016) juga }
$$
menuliskan, bahwa Karakteristik Mata Pelajaran Pendidikan Pancasila dan Kewarganegaraan (PPKn):

1. Mempersiapkan peserta didik menjadi warga negara yang memiliki komitmen kuat dan konsisten untuk mempertahankan NKRI.

2. Komitmen yang kuat dan konsisten terhadap prinsip dan semangat kebangsaan dalam kehidupan bermasyarakat, berbangsa, dan bernegara yang berdasarkan Pancasila dan Undang-Undang Dasar 1945.

3. Kehidupan yang demokratis di dalam kehidupan sehari-hari di lingkungan keluarga, sekolah, masyarakat.

4. Komitmen terhadap Kesadaran belanegara.

5. Ketaatan pada hukum, ketaatan membayar pajak, serta sikap dan perilaku anti korupsi, kolusi, dan nepotisme.

6. PPKn Fokus pada pembentukan warga negara yang memahami dan mampu 
melaksanakan hak-hak dan kewajibannya untuk menjadi warganegara Indonesia yang cerdas, terampil, dan berkarakter yang diamanatkan oleh Pancasila dan UUD 1945.

Dengan semakin merebaknya kasus penularan covid-19, maka menyebabkan pelaksanaan pembelajaran beralih menjadi Belajar Dari Rumah (BDR) (Santika, 2021a). Hal ini mau tidak mau membuat guru harus mencari metode untuk mengajar dari jarak jauh dengan aman dan efektif (Lede \& Swarniti, 2020). Maka dalam hal ini google classroom menjadi salah satu pilihan bagi penulis untuk mengoptimalkan pembelajaran jarak jauh selama masa pandemi covid-19.

Google classroom ini sudah biasa digunakan oleh penulis sebelum pandemi saat para peserta didik melaksanakan Praktik Kerja Lapangan (PKL) di dunia usaha, dunia industri, dan dunia kerja, dimana peserta didik tidak berada di sekolah, tetapi materi pembelajaran kelompok mata pelajaran muatan nasional seperti PPKn tetap bisa mereka pelajari melalui google classroom dimana saja, dan kapan saja.

Kondisi dan situasi pandemi covid-19 ini tidak menentu kapan akan berakhirnya, dan sebagai guru dalam melaksanakan pembelajaran perlu untuk memantau dan mengamati bagaimana kondisi para peserta didiknya guna menunjang proses pembelajaran, dan komunikasi secara langsung pun juga akan berpengaruh kepada proses pembelajaran yang dilaksanakan oleh guru, karena bagaimanapun sentuhan guru tidak bisa digantikan oleh teknologi secara keseluruhan. Untuk itu penulis memilih aplikasi zoom meeting untuk bertatap muka dengan peserta didik secara klasikal (Swarniti, 2021).

Dengan penggunaan google classroom dalam pembelajaran PPKn di Kelas XII APHP 1 materi pembelajaran, penugasan, dan penilaian dapat ditata berurutan sesuai dengan perencanaan pembelajran secara sistematis berdasarkan Kurikulum.

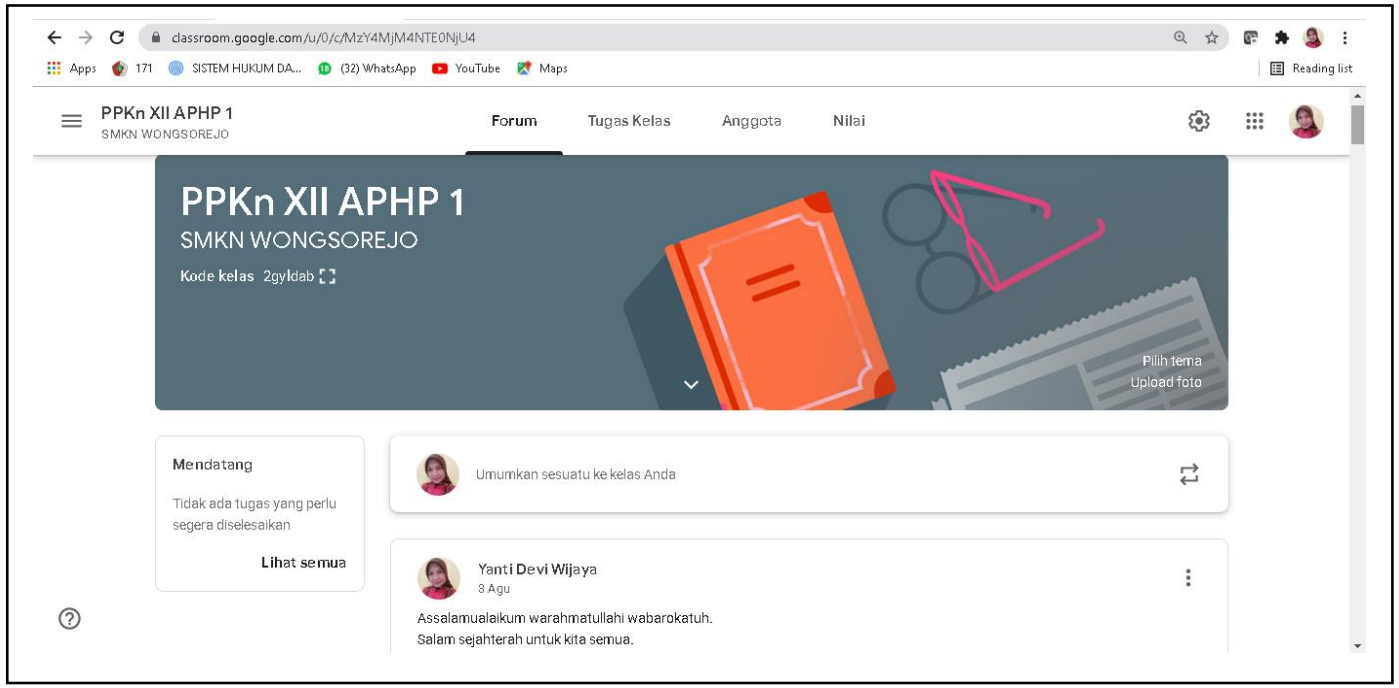

Gambar 1. Contoh tampilan Kelas Maya XII APHP 1 di google classroom 
Ada beberapa fitur yang sering kita gunakan pada awal di halaman depan Kelas Maya di google classroom, antara lain: 1. Forum

Forum ini adalah tempat dimana kita bisa memberikan info awal dan tata cara pembelajaran ataupun segala informasi yang berkaitan dengan pembelajaran secara umum, bisa diakses oleh semua anggota kelas, dan bisa dikomentari oleh semua anggota kelas. Pada Forum ini bisa digunakan untuk diskusi.

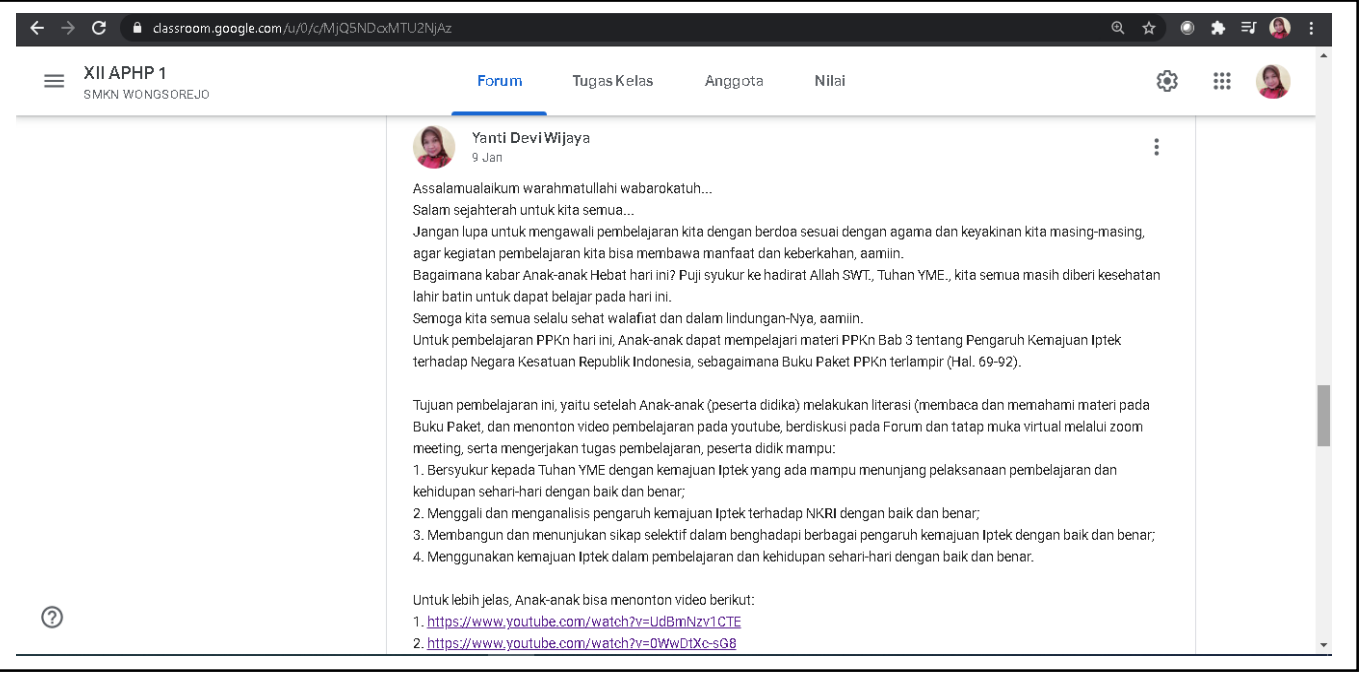

$\mathrm{amb}$

ar 2 .

Info

pad

a

For

um

di

Kel

as

$\mathrm{Ma}$

ya XII APHP 1 di google classroom

\section{Tugas Kelas}

Pada bagian Tugas Kelas ini kita bisa memanfaatkan untuk memberikan Materi pada siswa, atau Tugas dengan berbagai pilihan, kita juga bisa mengintegrasikan materi berupa video
Youtube, Quis dari google form, materi dari google slides, maupun google document, dan juga spreadsheet, baik untuk penugasan secara individu, maupun penugasan secara berkolaborasi. 


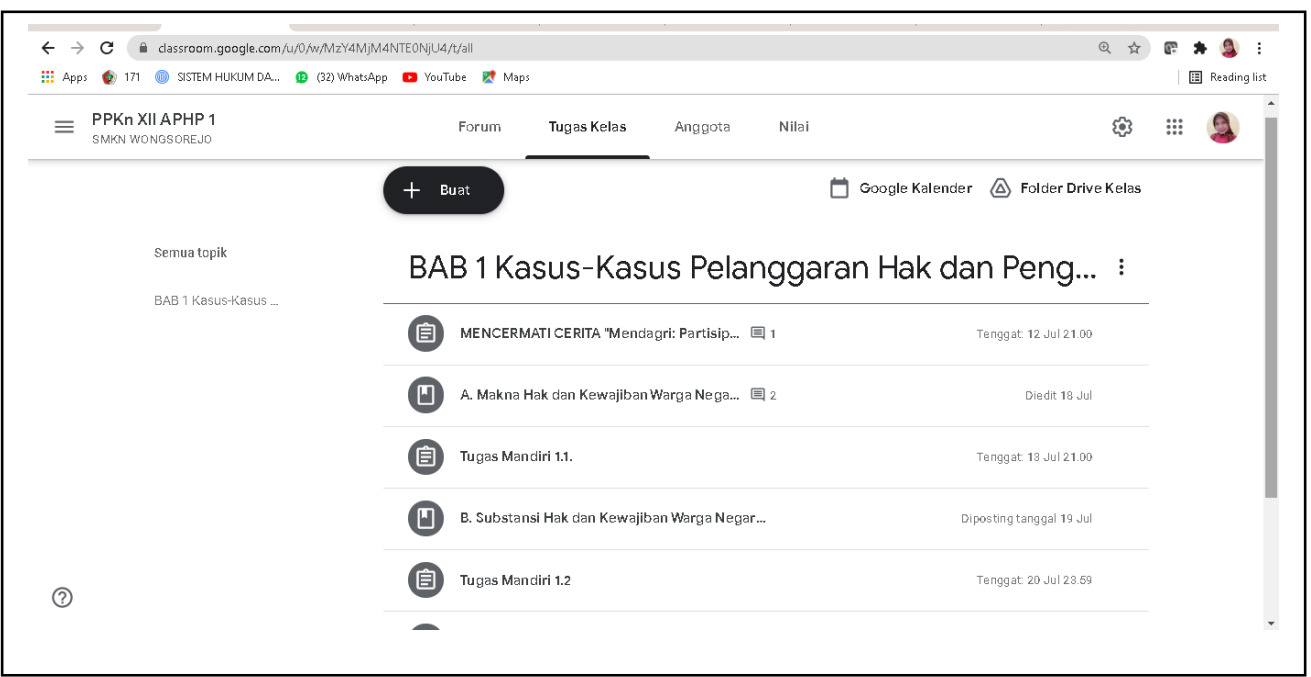

Gambar 3. Tampilan Materi dan Tugas Mandiri pada Tugas Kelas di google classroom

3. Anggota

Pada bagian Anggota ini terdapat sejumlah Guru dan Siswa yang tergabung dalam Kelas Maya. Di sini kita bisa mengatur, mengundang, mengeluarkan anggota

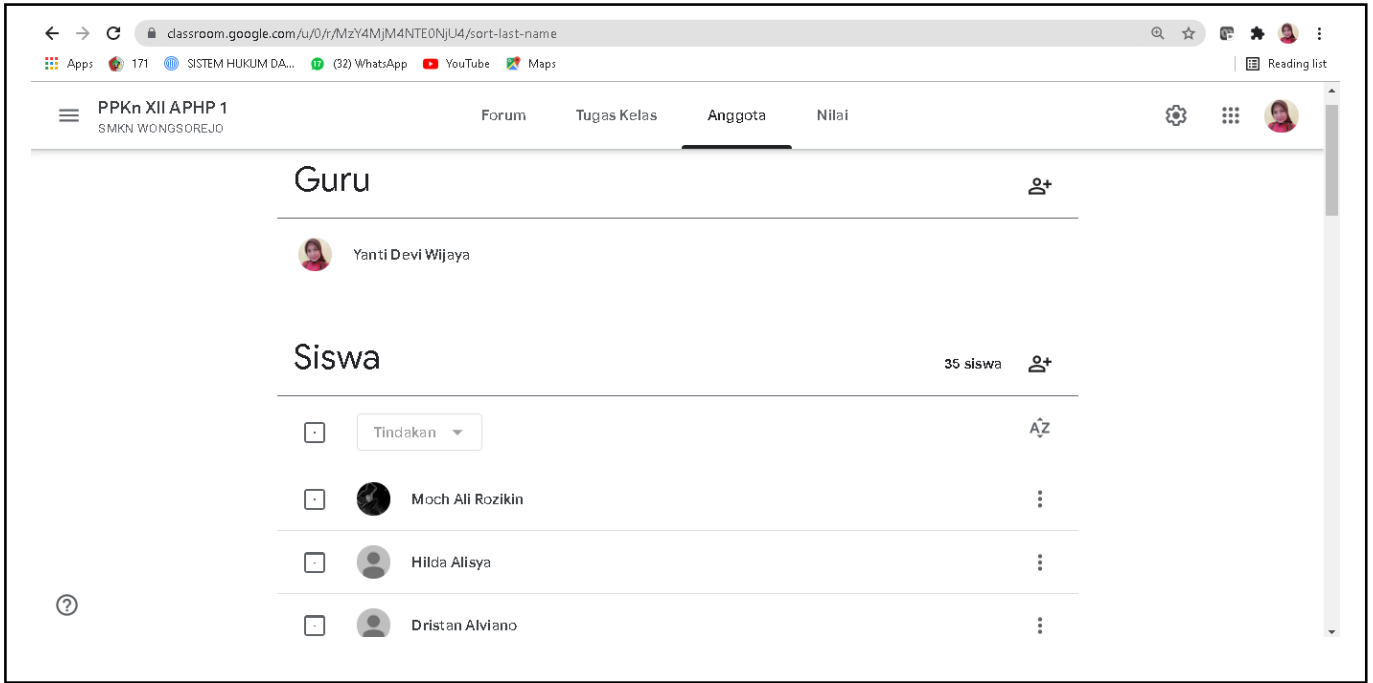

Gambar 4. Tampilan Anggota pada google classroom

4. Nilai

Pada bagian nilai ini kita bisa melihat nilai dari peserta didik yang sudah kita koreksi dan kita beri nilai dari hasil tugasnya. Untuk nilai ini bisa lebih tertata pada google classroom seperti buku nilai. 


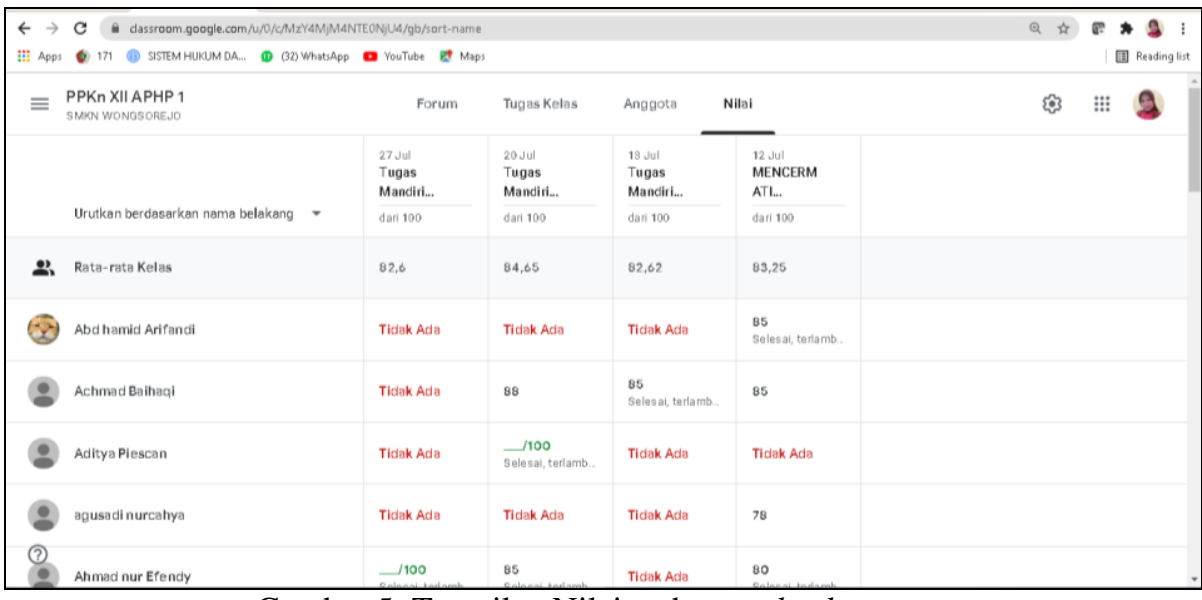

Gambar 5. Tampilan Nilai pada google classroom

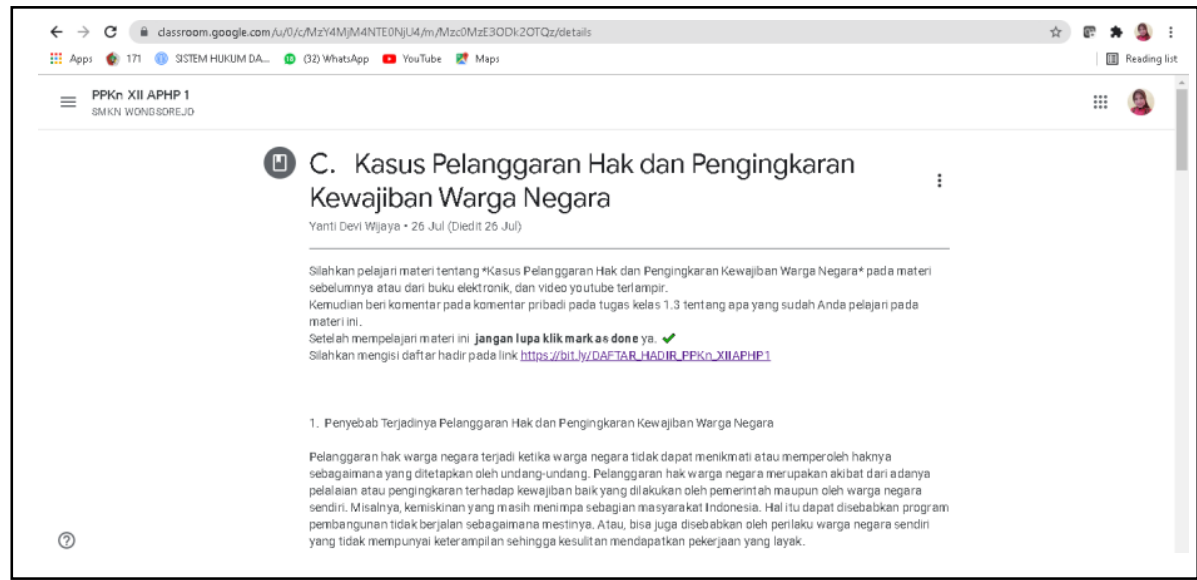

GGambar 6. Tampilan Materi pada Tugas Kelas di google classroom

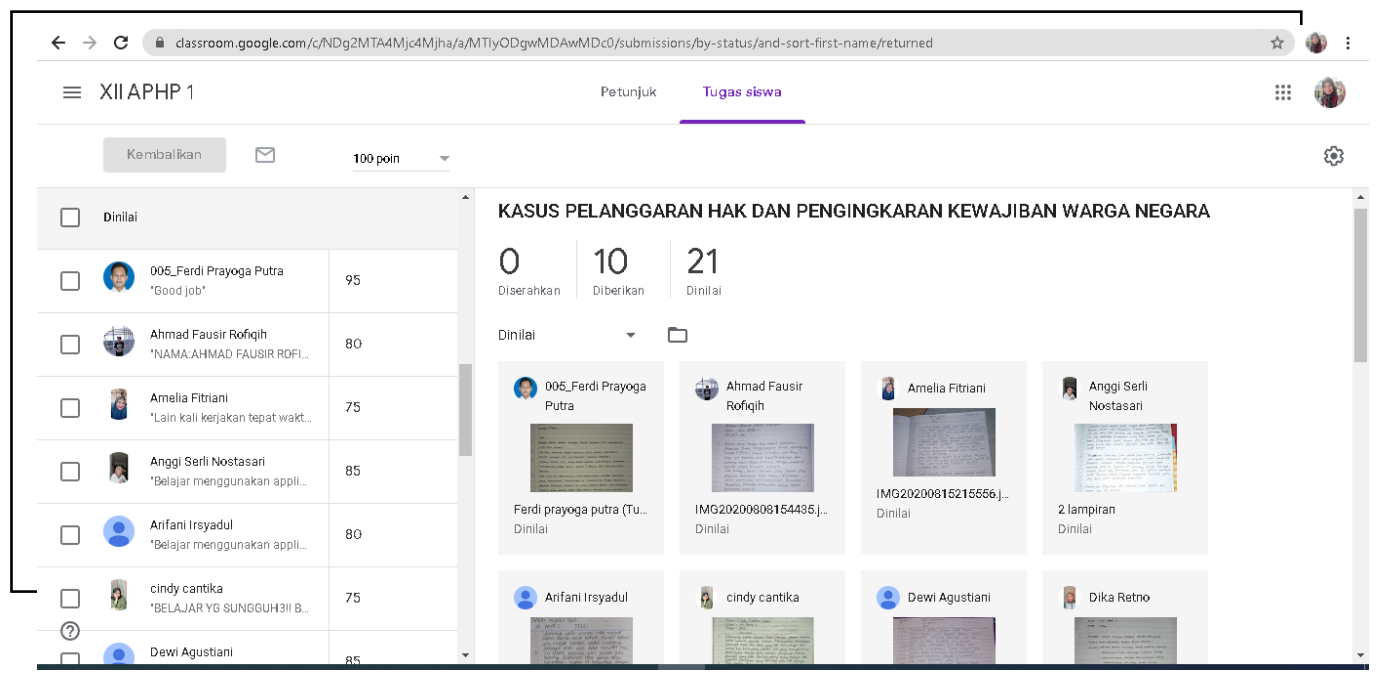


Dengan menggunakan google classroom dalam pembelajaran PPKn pada kelas XII APHP 1 di SMKN Wongsorejo pada
Semester Gasal Tahun Pelajaran 2020/2021

diperoleh hasil sebagaimana tabel berikut.

Tabel 1. Perkembangan Hasil Tugas Pembelajaran Peserta Didik Kelas XII APHP 1

Semester Gasal Tahun Pelajaran 2020/2021

Mata Pelajaran PPKn Bab 1

\begin{tabular}{|c|c|c|c|c|c|c|c|c|c|c|}
\hline \multicolumn{2}{|c|}{ Ketuntasan Belajar Minimum = 60} & & & & & & & & & \\
\hline \multirow[b]{2}{*}{ NO } & \multirow[b]{2}{*}{ NAMA } & \multicolumn{5}{|c|}{ BAB 1} & \multirow[b]{2}{*}{$\begin{array}{c}\text { Ulangan } \\
\text { Harian } \\
\text { Bab1 }\end{array}$} & \multirow[b]{2}{*}{$\begin{array}{c}\text { Nilai } \\
\text { Tengah } \\
\text { Semester }\end{array}$} & \multirow[b]{2}{*}{$\begin{array}{c}\text { Rata-rata } \\
\text { Ketuntasan }\end{array}$} & \multirow[b]{2}{*}{ KETERANGAN } \\
\hline & & TUGAS 1 & TUGAS 2 & TUGAS 3 & TUGAS 4 & TUGAS 5 & & & & \\
\hline \multicolumn{2}{|r|}{ Prosentase Ketuntasan Klasikal --> } & $83 \%$ & $80 \%$ & $70 \%$ & $73 \%$ & $80 \%$ & $37 \%$ & $70 \%$ & $70 \%$ & Tuntas \\
\hline 1 & AHMAD FAUSIR ROFIQIH & 90 & 85 & 80 & 78 & 90 & 80 & 80 & $83 \%$ & Tuntas \\
\hline 2 & ALAN FIGO YANWAR & 0 & 0 & 0 & 85 & 78 & 0 & 0 & $23 \%$ & Tidak Tuntas \\
\hline 3 & ALIMATUL AMELIA & 90 & 85 & 0 & 0 & 90 & 0 & 88 & $50 \%$ & Tidak Tuntas \\
\hline 4 & AMANDA JESSICA BERLIANDA & 90 & 0 & 78 & 78 & 90 & 80 & 88 & $72 \%$ & Tuntas \\
\hline 5 & AMILIA FITRIANI & 85 & 85 & 75 & 0 & 0 & 0 & 0 & $35 \%$ & Tidak Tuntas \\
\hline 6 & ANDI ISMAIL & 0 & 0 & 0 & 0 & 0 & 0 & 0 & $0 \%$ & Tidak Tuntas \\
\hline 7 & ANGGI SERLI NOSTASARI & 90 & 95 & 85 & 85 & 88 & 90 & 88 & $89 \%$ & Tuntas \\
\hline 8 & ARIFANI IRSYADULIBAD & 85 & 85 & 80 & 0 & 0 & 0 & 78 & $47 \%$ & Tidak Tuntas \\
\hline 9 & ARIS SETIAWAN & 0 & 80 & 0 & 0 & 0 & 0 & 78 & $23 \%$ & Tidak Tuntas \\
\hline 10 & CINDY CANTIKA PUTRI & 85 & 85 & 0 & 80 & 88 & 80 & 80 & $71 \%$ & Tuntas \\
\hline 11 & DEWI AGUSTIANI & 85 & 85 & 85 & 80 & 88 & 0 & 80 & $72 \%$ & Tuntas \\
\hline 12 & DIKA RETNO SAFITRI & 90 & 90 & 85 & 80 & 90 & 90 & 90 & $88 \%$ & Tuntas \\
\hline 13 & DIMAS HARTAWAN & 85 & 78 & 0 & 80 & 85 & 0 & 78 & $58 \%$ & Tidak Tuntas \\
\hline 14 & DWI ARIYANTI RUKMANA DEWI & 90 & 85 & 78 & 80 & 85 & 0 & 80 & $71 \%$ & Tuntas \\
\hline 15 & DWI NUR WAHYUNI & 85 & 80 & 78 & 85 & 85 & 0 & 0 & $59 \%$ & Tidak Tuntas \\
\hline 16 & EGA DWI YULINAR & 85 & 80 & 90 & 78 & 85 & 0 & 80 & $71 \%$ & Tuntas \\
\hline 17 & FAJAR AINUR ROFIQIH & 0 & 0 & 0 & 0 & 0 & 0 & 0 & $0 \%$ & Tidak Tuntas \\
\hline 18 & FEBRIANSYAH DWI MAULANA & 0 & 0 & 0 & 0 & 0 & 0 & 0 & $0 \%$ & Tidak Tuntas \\
\hline 19 & FERDI PRA YOGA PUTRA & 90 & 85 & 95 & 90 & 90 & 95 & 90 & $91 \%$ & Tuntas \\
\hline 20 & FITRIATULHASANAH & 95 & 90 & 80 & 85 & 85 & 90 & 90 & $88 \%$ & Tuntas \\
\hline 21 & GALANGPRIMA ARTHA & 90 & 85 & 75 & 80 & 90 & 0 & 0 & $60 \%$ & Tuntas \\
\hline 22 & HERU MUZZAMMIL & 90 & 85 & 80 & 80 & 80 & 90 & 90 & $85 \%$ & Tuntas \\
\hline 23 & HOSNUL HOTIMAH & 95 & 90 & 90 & 85 & 90 & 90 & 90 & $90 \%$ & Tuntas \\
\hline 24 & IDA WAHIDA & 95 & 85 & 90 & 85 & 85 & 0 & 95 & $76 \%$ & Tuntas \\
\hline 25 & IKE NUR SAFITRI & 90 & 85 & 0 & 80 & 85 & 0 & 85 & $61 \%$ & Tidak Tuntas \\
\hline 26 & INDRI KHARISMA & 90 & 95 & 85 & 85 & 85 & 90 & 88 & $88 \%$ & Tuntas \\
\hline 27 & IZEY FEBRIYANTO & 85 & 0 & 90 & 80 & 80 & 0 & 0 & $48 \%$ & Tidak Tuntas \\
\hline 28 & JULIA INDAHFATMAWATI & 90 & 85 & 88 & 80 & 85 & 0 & 88 & $74 \%$ & Tuntas \\
\hline 29 & LUDIYA & 100 & 90 & 85 & 80 & 85 & 80 & 88 & $87 \%$ & Tuntas \\
\hline 30 & MARIYANI & 75 & 75 & 60 & 0 & 75 & 0 & 0 & $41 \%$ & Tidak Tuntas \\
\hline 1 & Prosentase Ketidaktuntasan Klasikal --> & $17 \%$ & $20 \%$ & $30 \%$ & $27 \%$ & $20 \%$ & $63 \%$ & $30 \%$ & $30 \%$ & Tidak Tuntas \\
\hline
\end{tabular}

Dari tabel di atas secara klasikal ketuntasan pembelajaran peserta didik kelas XII APHP 1 pada Bab 1mata pelajaran PPKn adalah sebanyak 70\%. Data tersebut diperoleh dari data nilai yang ada pada google classroom.

Terlihat pada table tersebut ada peserta didik yang tidak aktif dalam pembelajaran pada google classroom, yaitu 3 (tiga) anak dengan prosentase ketuntasan $0 \%$, dan dan yang selalu aktif sebanyak 8 (delapan) peserta didik, sedangkan sisanya 19 (sembilan belas) peserta didik masih terlihat terkadang tidak aktif. 
Pada perkembangan pembelajaran pada tabel berikut:

selanjutnya, hasil pembelajaran bisa tergambar

Tabel 2. Keaktifan Peserta Didik kelas XII APHP 1 pada pembelajaran PPKn

Di Semester Gasal Tahun Pelajaran 2020/2021

\begin{tabular}{|c|c|c|c|c|c|c|}
\hline $\begin{array}{c}\text { Pembelajaran pada } \\
\text { Materi }\end{array}$ & \multicolumn{2}{|c|}{$\begin{array}{c}\text { Peserta Didik } \\
\text { yang selalu aktif }\end{array}$} & \multicolumn{2}{|c|}{$\begin{array}{c}\text { Peserta Didik } \\
\text { yang terkadang } \\
\text { tidak aktif }\end{array}$} & \multicolumn{2}{|c|}{$\begin{array}{c}\text { Peserta didik } \\
\text { yang tidak } \\
\text { pernah aktif }\end{array}$} \\
\hline BAB 1 & 8 & $27 \%$ & 19 & $63 \%$ & 3 & $10 \%$ \\
\hline BAB 2 & 6 & $20 \%$ & 24 & $80 \%$ & 0 & $0 \%$ \\
\hline BAB 3 & 6 & $20 \%$ & 20 & $67 \%$ & 4 & $13 \%$ \\
\hline
\end{tabular}

Dari komunikasi dengan peserta didik secara virtual dan melalui grup wahtsapp kelas, hambatan dalam pembelajaran secara online dengan menggunakan google classroom ini antara lain beberapa peserta didik terkadang tidak memiliki paket data pada saat pembelajaran, dan susahnya sinyal pada lokasi peserta didik melaksanakan pembelajaran.

$$
\text { Danin Haqien dan Aqiilah }
$$

Afiifadiyah Rahman (2020) menuliskan, bahwa

Zoom Meeting merupakan sebuah media pembelajaran menggunakan video. Pendiri aplikasi Zoom Meeting yaitu Eric Yuan yang diresmikan tahun 2011, yang berkantor pusatnya di San Jose, California. Aplikasi ini tidak hanya digunakan untuk pembelajaran saja tetapi bisa digunakan untuk urusan perkantoran maupun urusan lainnya. Platfrom ini gratis untuk batas waktu empat puluh menit dan tidak ada batasan waktu jika akun kita berbayar. Dalam aplikasi Zoom Meeting ini kita bisa berkomunikasi langsung dengan siapapun lewat video. Oleh karena itu, penulis menggunakannya dalam pelaksanaan pembelajaran selama pandemi covid-19 sebagai media menunjang dalam tatap muka virtual dengan peserta didik untuk menjaga dan melaksanakan protocol kesehatan dalam penerapan physical distancing. 


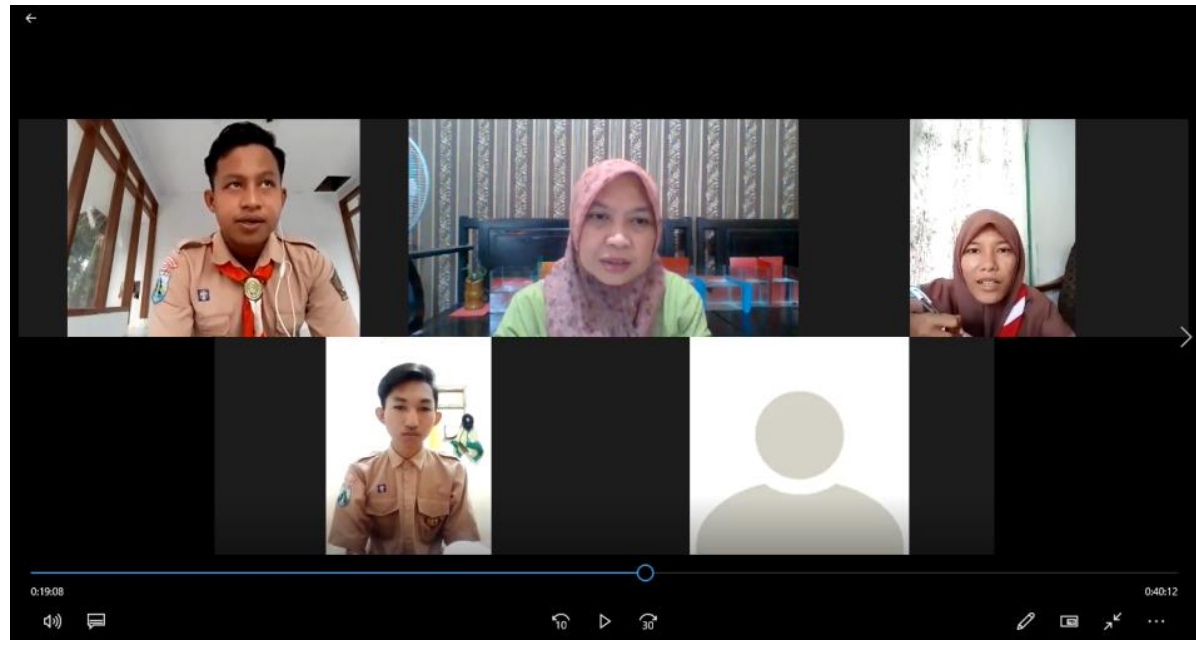

Gambar 8. Hasil record pertemuan virtual dengan peserta didik

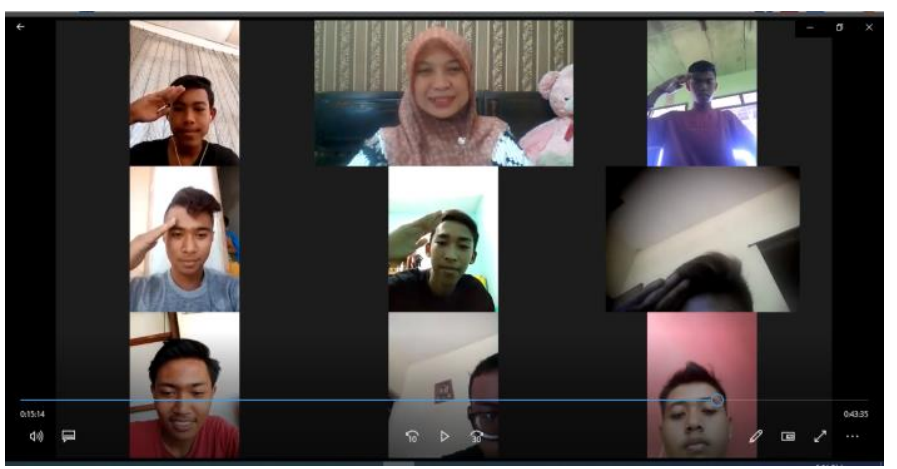

Gambar 8. Hasil record pertemuan virtual dengan peserta didik di akhir pembelajaran

Penggunaan zoom meeting dalam pembelajaran untuk tatap muka virtual cukup efektif selama masa pandemi covid-19, karena antara guru dan peserta didik dapat bertatap muka secara virtual, menjelaskan materi baik dengan media presentasi berupa power point, maupun dengan menggunakan video youtube yang ditampilkan pada saat tatap muka virtual dengan menggunakan zoom meeting, pembelajaran dapat berlangsung sebagaimana tatap muka di kelas, termasuk melakukan tanya jawab, dan berdiskusi secara virtual antara guru dengan peserta didik, maupun antar peserta didik dengan bimbingan guru, dengan tetap menerapkan protokol kesehatan masa pandemi, yaitu phisical distancing, karena semua peserta didik berada pada tempat masing-masing.

$$
\text { Tetapi sebagaimana gambar }
$$

dokumentasi hasil record tatap muka virtual dengan menggunakan zoom meeting sebagaimana pada gambar 7 dan gambar 8 , terlihat peserta tidak terlalu banyak sebagaimana pembelajaran tatap muka langsung sebelum masa pandemi covid-19. Hal ini juga disebabkan kendala peserta didik yang tidak memiliki paket data untuk mengikuti pelaksanaan pembelajaran secara virtual, dan juga ada sebagian yang terkendala karena sinyal jaringan internet yang kurang mendukung. 
Dari hasil angket penggunaan google classroom dan zoom meeting dalam pembelajaran PPKn kepada peserta didik kelas XII APHP 1, didapat hasil seperti berikut:

1. Apakah penggunaan google classroom dalam pembelajaran PPKn sangat membantu pada saat kondisi Pandemi
Covid-19, dimana untuk mencegah penyebaran virus tersebut?

Hasil: 44\% menjawab cukup membantu, 565 sangat membantu.

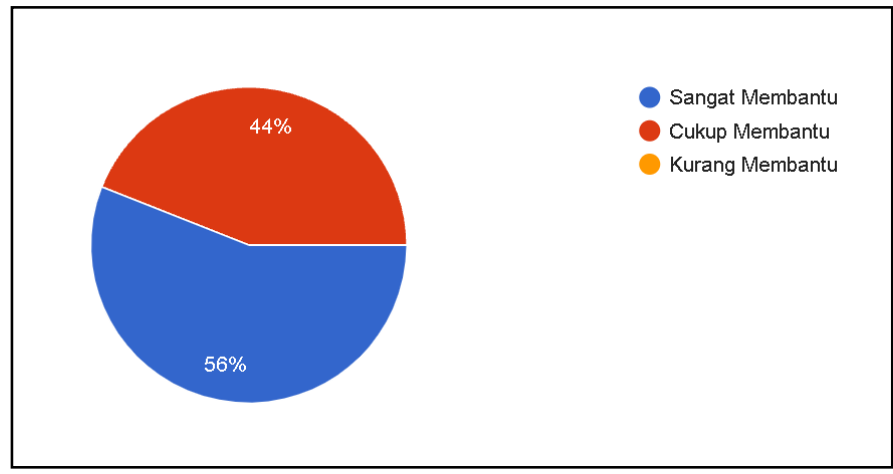

Gambar 9. Prosentase penggunaan google classroom membantu dalam pembelajaran saat pandemi covid-19

2. Apakah penggunaan Zoom dalam tatap muka virtual membantu dalam pembelajaran PPKn?

Hasil: 32\% Sangat Membantu, 56\% Cukup Membantu, 12\% Kurang Membantu

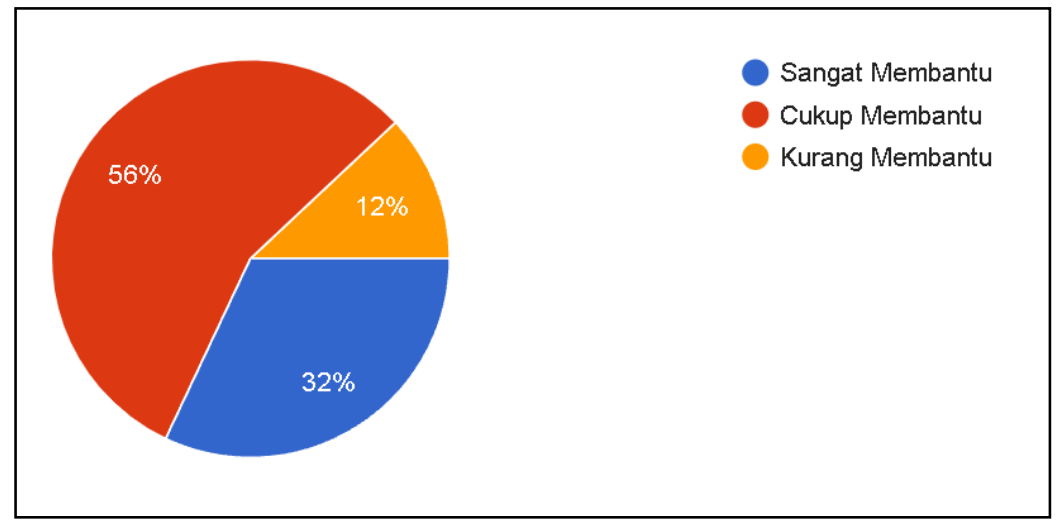

Gambar 10. Prosentase penggunaan zoom meeting membantu dalam pembelajaran saat pandemi covid-

19

3. Apa keuntungan yang Anda dapatkan dalam pembelajaran dengan menggunakan google classroom dalam pembelajaran PPKn selama masa Pandemi Covid-19? 
Hasil: beberapa jawaban keuntungan yang didapatkan oleh peserta didik dengan menggunakan google classroom dalam pembelajaran PPKn selama masa pandemi covid-19 antara lain:

a. Meringankan tugas yang diberikan guru.

b. Bisa belajar di rumah.

c. Belajar sungguh-sungguh.

d. Google classroom merupakan sarana pembelajaran terbaik di kala masa pandemi ini, saya jadi bisa belajar sedikit demi sedikit dimengerti meskipun teori harus belajar sendiri tanpa arahan guru secara langsung.

e. Bisa belajar dengan jarak jauh atau secara online.

f. Dapat membantu untuk terus belajar, bisa mengumpulkan tugas dimana saja, efektif waktu dalam mengerjakan tugas PPKn

g. Meningkatkan kerjasama dan komunikasi, serta mempermudah siswa mengerjakan tugas atau diskusi secara online.

h. Menambah pengetahuan.

i. Keuntungannya adalah kita bisa memahami lebih detail lagi tentang classrom yang dulu tidak tahu aplikasi itu sekrang saya bisa memahaminya.

j. Mengerjakan tugas tidak buru-buru karena sudah ada batas waktu yang ditentukan

k. Mencoba belajar lewat online.

1. Guru dapat mengirimkan pemberitahuan ke peserta atau siswa mereka untuk memulai diskusi online atau memberitahu mereka tentang kegiatan pembelajaran online tertentu.

m. Keuntungan dalam menggunakan classroom lumayan ada contohnya dalm mengumpulkan tugas kita kadang dapat melihat nilai terkadang ada guru yg memberi tugas menggukan classroom langsung diberi nilai.

n. Lebih praktis dalam mengirim tugas.

o. Tugas dapat dikerjakan dimana saja.

p. Bisa saling bertanya sesama teman, jika tidak paham dengan tugasnya.

q. Keuntungan yang saya dapatkan dengan adanya pembelajaran melalui google classroom adalah saya tetap bisa mendapatkan materi PPKn selama masa Pandemi Covid-19.

r. Tetap bisa mengikuti pelajaran dan tetap bisa mempelajari materi PPKn walaupun tidak secara tatap muka.

s. Saya dapat belajar di rumah dengan baik saat pandemi ini.

t. Meskipun tidak masuk sekolah secara maksimal, Alhamdulillah ada google classroom sangat membantu kita untuk memahami pelajaran yang ada.

u. Dapat mengikuti semua mata pelajaran terutama mata pelajaran PPKn dan tentunya juga mendapatkan wawasan dan pengetahuan meskipun tidak belajar secra lansung.

v. Lebih mudah memhami dan lebih nyaman jika mengumpulkan tugas.

w. Mempermudah pengiriman tugas 
x. Keuntungannya adalah kita bisa memahami materi yang diajarkan oleh bapak/ibu guru.

4. Apa keuntungan yang Anda dapatkan dalam pembelajaran dengan menggunakan zoom meeting dalam pembelajaran PPKn selama masa Pandemi Covid-19?

Hasil: beberapa jawaban keuntungan yang didapatkan oleh peserta didik dengan menggunakan zoom meeting dalam pembelajaran PPKn selama masa pandemi covid-19 antara lain:

a. Menambah wawasan dan kemampuan menggunakan berbagai aplikasi dalam proses pembelajaran.

b. Dapat berlajar bertatap muka.

c. Bisa bertatap muka bersama temanteman. Semangat!

d. Bisa tatap muka secara virtual, dan agar bisa proses pembelajaran PPKn terus berjalan lancar.

e. Mempermudah siswa untuk diskusi dan berinteraksi secara bertatap muka.

f. Keuntungannya adalah kita masih bisa scara langsung menyampaikan materi.

g. Dapat mengerti pelajaran meskipun sedikit.

h. Saya mendapatkan pembelajaran tidak langsung tetapi bisa tatap muka.

i. Dapat mencerna penjelasan yang lebih detail dari bapak/ibu guru karena itu sangat penting untuk proses belajar kita di masa pandemi ini. dan juga bisa bertatap muka walaupun virtual.

j. Sedikit lebih mengerti materi.

k. Dapat berinteraksi dengan guru tanpa tatap muka langsung.

1. Bisa bertatap muka, walaupun jarak jauh.

m. Saya bisa mendengarkan penjelasan mengenai materi-materi yang ada dalam pembelahan PPKn selama Pandemik Covid-19.

n. Bisa komunikasi langsung seperti tatap muka dengan guru pembingbing.

o. Saya dapat mengikuti pembelajaran tatap muka secara virtual untuk memahami tugas atau materi yang disampaikan oleh guru.

p. Dapat menambah wawasan kita dengan cara zoom

q. Bisa saling sapa atau temu kangen sama bu Yanti dan temen-temen kelas 12 APHP 1 dan bisa bertanya dan saling memberi pendapat.

r. Lebih mudah faham karena dijelaskan secara langsung dan bisa melihat muka teman-teman.

s. Dapat belajar bersama walaupun dengan virtual, yaitu kita bisa memahami lebih detail dan akurat materi pembelajaran.

5. Apa kendala Anda dalam menggunakan google classroom dalam pembelajaran PPKn selama masa Pandemi Covid-19?

Hasil:

a. Kendalanya adalah notif kadang-kadang tidak ada atau terlewatkan.

b. Kendalanya pada paketan dan jaringan.

c. Tidak ada, saya saja yang kurang giat

d. Kuota data sering habis.

e. Akses internet tidak lancar.

f. Kouta internet menjadi masalah.

g. Belum tercukupinya kebutuhan kuota internet siswa secara memadai.

h. Susah sinyal.

i. Terbatasnya kouta yang digunakan

j. Sering susah sinyal untuk upload tugas apalagi dalam bentuk vedio.

k. Kendala saya jika tidak ada kouta, dan jaringan putus-putus.

1. Ram HP tidak cukup sehingga tidak bisa menyimpan aplikasi dan susah untuk mengerti materi yang dipelajari. 
m. Ada susah untuk membuat file PDF, HP tidak memadai karena ram kurang besar .

n. Hp terkadang lemot dan susah sinyal.

o. Kendalanya sinyal kurang bagus karena rumah saya di dataran tinggi.

6. Apa kendala Anda dalam menggunakan zoo meeting dalam pembelajaran PPKn selama masa Pandemi Covid-19?

Hasil:

a. Paketan dan jaringan

b. Terkadang bangun kesiangan

c. Butuh internet yang super stabil, sedangkan zoom boros penggunaan kuota data.

d. Boros dalam penggunaan kuota

e. Kepemilikan handphone yang belum dimiliki oleh seluruh siswa.

f. Terbatasnya kouta.

g. Sinyal jaringan terkadang yang sulit membuat saya tidak bisa mengikuti zoom.

h. Karena file penyimpanan yang tidak cukup dan kuota yang tidak memadai.

1. Tidak punya paketan 2. Susah sinyal 3 . Ram hp tidak cukup sehingga tidak bisa menyimpan aplikasi 4.

m. Tidak memiliki kuota data, kadang juga disuruh membantu orang tua jadi tidak bisa meng ikuti zoom meeting.

n. Sinyal kurang baik dan suaranya putusputus

\section{PENUTUP}

Simpulan

Pandemi Covid-19 telah banyak membawa perubahan dalam segala aspek kehidupan manusia, baik dalam bidang sosial kemasyarakatan, maupun ekonomi. Tidak luput juga pada bidang pendidikan, yang mengharuskan perubahan pada moda pelaksanaan pembelajaran dari konvensional secara tatap muka langsung di sekolah menjadi moda daring (dalam jaringan) secara online dengan menggunakan jaringan internet.

Dengan adanya wabah covid-19 yang mulai masuk ke Indonesia sejak ditemukan kasus pertama di bulan Maret 2020, kegiatan pembelajaran diharuskan dilakukan secara online dengan pertimbangan mengutamakan kesehatan dan keselamatan peserta didik, guru, dan tenaga kependidikan, serta keluarganya, dan juga masyarakat.

Dengan kondisi yang seperti itu, mau tidak mau guru dan peserta didik diharuskan mampu untuk melaksanakan pembelajaran secara online, dipaksa harus secara cepat untuk mampu menguasai dan menerapkan ilmu pengetahuan dan teknologi informasi serta komunikasi yang terintegrasi dalam pembelajaran.

Untuk mengatasi hal tersebut peneliti berusaha memilih media yang mengintegrasikan teknoligi informasi dan komunikasi dalam pelaksanaan pembelajaran PPKn selama masa pandemi covid-19 di kelas XII APHP 1 SMKN Wongsorejo, seahingga peneliti mencoba menggunakan google classroom sebagai media untuk kelas maya tempat bertemunya pendidik dengan peserta didik, yang di dalamnya bisa digunakan untuk memanajemen pembelajaran mulai dari berkomunikasi secara online, memberikan materi, penugasan, penilaian, dan umpan balik, yang divariasi dengan menggunakan zoom meeting untuk melakukan pertemuan secara virtual antara pendidik dan peserta didik. 
Dalam kondisi pandemi covid-19, penggunaan google classroom dan zoom meeting dapat diterapkan untuk mengatasi masalah pelaksanaan pembelajaran PPKn selama masa pandemi covid-19 di Kelas XII APHP 1 SMKN Wongsorejo dengan cukup efektif, meski terdapat beberapa kendala mulai dari masalah kebutuhan pemenuhan paket data, kendala susah sinyal, maupun kendala dari diri peserta didik yang terkadang malas untuk belajar secara online, dan juga kendala peserta didik yang harus membantu orang tua, sehingga tidak dapat mengikuti pembelajaran secara online.

\section{Saran}

Dari berbagai kendala dalam pelaksanaan pembelajaran secara online atau dalam jaringan (daring) selama masa pandemi covid-19, perlu adanya komunikasi yang efektif antara sekolah, guru, wali kelas, guru Bimbingan dan Konseling, dan juga terutama orang tua siswa, demi berjalannya dan keberhasilan pelaksanaan pembelajaran secara online atau daring.

Dalam beberapa hal sangat diperlukan peran serta orang tua terhadap dukungan pembelajaran peserta didik, karena bagaimana pun juga dukungan orang tua, baik berupa perhatian dan dana untuk proses pembelajaran dari peserta didik sangat diperlukan.

Ke depan dari hasil penelitian ini perlu penelitian lebih lanjut dengan penambahan penerapan komunikasi guru dengan orang tua untuk keberhasil pembelajaran dan pendidikan peserta didik.

\section{DAFTAR PUSTAKA}

Fauziyah, Minik Rinayanti, 2020, Cara Praktis Menggunakan Google Classroom, Deeppublish, Yogyakarta.

Danin Haqien dan Aqiilah Afiifadiyah Rahman, Pemanfaatan Zoom Meeting Untuk Proses Pembelajaran Pada Masa Pandemi Covid-19, SAP (Susunan Artikel Pendidikan) Vol. 5 No. 1 Agustus 2020, tersedia (online): https://garuda.ristekbrin.go.id/docum ents/detail/2101911, diakses pada 21 Juni 2021

Amin Hasan, 2021, Pengertian, Karakteristik, dan Manfaat E-learning, tersedia online:

http://www.smkbkujkt.sch.id/read/16 /pengertian-karaktiristik-danmanfaat-eLearning, diakses tanggal 21 Juni 2021.

Ati Rosidah, 2020, Pemanfaatan Google Classroom untuk Pembelajaran Online, tersedia (online): https://lpmpdki.kemdikbud.go.id/pe manfaatan-google-classroom-untukpembelajaran-online/, diakses tanggal 21 Juni 2021.

Lede, D. A. S., \& Swarniti, N. W. (2020). IMPROVING THE STUDENTS' VOCABULARY MASTERY BY

USING TREE DIAGRAM ON THE EIGHTH GRADE STUDENTS' OF SMP DWIJENDRA IN THE ACADEMIC YEAR 2019/2020.

Widyasrama, 30(2), 51-57. 
Santika, I. G. N. (2020a). Menggali dan Menemukan Roh Pancasila Secara Kontekstual. Lakeisha.

Santika, I. G. N. (2020b). Optimalisasi Peran Keluarga Dalam Menghadapi Persoalan Covid- 19 : Sebuah Kajian Literatur. Jurnal Ilmiah Ilmu Sosial, 6(2), 127-137. https://doi.org/http://dx.doi.org/10.23887/ jiis.v6i2.28437

Santika, I. G. N. (2021a). Grand Desain Kebijakan Strategis Pemerintah Dalam Bidang Pendidikan Untuk Menghadapi Revolusi Industri 4.0. Jurnal Education and Development, 9(2), 369-377.

Santika, I. G. N. (2021b). Pendidikan Kewarganegaraan (Studi Komparatif Konstitusi Dengan UUD 1945). Lakeisha. Santika, I. G. N. (2021c). Tinjauan Historis Terhadap Keppres No. 24 Tahun 2016 Tentang Hari Lahir Pancasila. Vyavahara Duta, XVI(2), 5-24.

https://doi.org/http://dx.doi.org/10.25078/ vd.v16i2.2384

Santika, I. G. N., Kartika, I. M., Ayu, I. G., \& Darwati, M. (2021). Reviewing The Handling Of Covid-19 In Indonesia In The Perspective Of The Pancasila Element Theory ( TEP ). Jurnal Etika Demokrasi (JED), 6(2), 40-51. https://doi.org/https://doi.org/10.26618/je d.v6i2.5272

Santika, I. G. N., Rindawan, I. K., \& Sujana, I.

G. (2018). Memperkuat Pancasila Melalui Pergub No. 79 Tahun 2018 Dalam Menanggulangi Pengikisan Budaya Di Era Revolusi Industri 4.0. Seminar
Nasional Inovasi Dalam Penelitian Sains, Teknologi Dan Humaniora-InoBali, 79, 981-990.

Swarniti, N. W. (2020). Fenomena Morfologi pada Berita-Berita di CNN Indonesia Mengenai Covid-19: Kajian Linguistik. In COVID-19 Perspektif Susastra dan Filsafat (p. 93). Yayasan Kita Menulis.

Swarniti, N. W. (2021). Efektivitas Penggunaan Aplikasi Quizizz Dalam Proses Pembelajaran Bahasa Inggris Bagi Mahasiswa. Seminar Nasional Teknologi Pembelajaran, 133-144.

Sucahyono MJ., 2016, Guru Pembelajar, Modul Pelatihan SD Kelas Awal, tersedia (online):

http://repositori.kemdikbud.go.id/103 4/1/Gabung\%20Rekon\%20SD\%20a wal\%20kk\%20G.ok.pdf, di akses pada 21 Juni 2021. 